Vol. 3, No. 1, 2021

https://doi.org/10.23939/cds2021.01.031

UDK 534.843:004.9

R. Holovatskyy, M. Lobur

Lviv Polytechnic National University

\title{
DETERMINATION OF BOUNDARY CONDITIONS FOR THE RADIATION PATTERN OF A MICROELECTRO-OPTICAL INTELLIGENT PASSIVE INFRARED MOTION DETECTOR
}

\author{
(C) Ruslan Holovatskyy, Mykhaylo Lobur, 2021
}

In this paper, a block diagram of a microelectro-optical intelligent passive infrared motion detector is proposed. On the basis of the proposed structural scheme and analytically conducted synthetic processing of information from primary sources [5-17], boundary conditions for the directivity diagram of such a detector are determined. The analytical information collected in this article will be necessary for further modeling in computer-aided design with a view to new developments and improvements to existing motion detectors.

Key words - security systems, IR motion detectors, radiation patterns, block diagram, schematic diagram, recognition efficiency.

\section{INTRODUCTION}

The development of modern technology in the 21st century has led to the rapid proliferation of lowcost but effective tools and devices for building security systems. An integral part of modern security systems, and perhaps the most important element of them, is a passive infrared motion detector - a device that allows you to detect movement in a given detection zone based on changes in its temperature background. Motion detectors are widespread and analysts expect their usage to grow by another $13 \%$ $14 \%$ annually by 2020 [1]. According to experts, the use of motion detectors in residential homes and offices will grow by $20 \%$ a year over the same period, with the largest growth expected in Europe, Ukraine and Russia, especially in the field of foreign penetration protection and other aspects home automation.

\section{MODERN PYROELECTRIC MOTION DETECTORS}

A typical view of a modern pyroelectric motion detector is shown in Fig. 1. As can be seen from the figure, the detector has an active window in which the Fresnel lens is placed. Most well-known companies produce detectors in which you can change the configuration of the lenses depending on the specifics of the object to be protected.
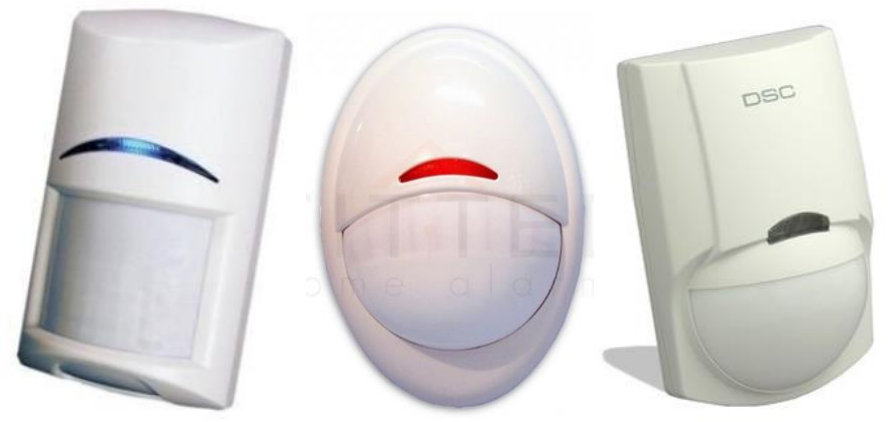

Fig.1. A typical view of a modern pyroelectric motion detector.

Constructive and schematic features of detectors should include their versatility and intelligence, which consists in the presence of adjusting elements, namely variable resistors and other external controls and adjusting detectors during its installation and subsequent operation, which can be clearly seen in Fig. 2. 
This feature appears because the professional, accurate setting of a pyroelectric motion detector is essential for its reliable, accurate and high quality operation. Because there are many factors that cause its false positives, it entails additional material and moral costs. Developing an intelligent motion detector that avoids manual tuning is an important task.
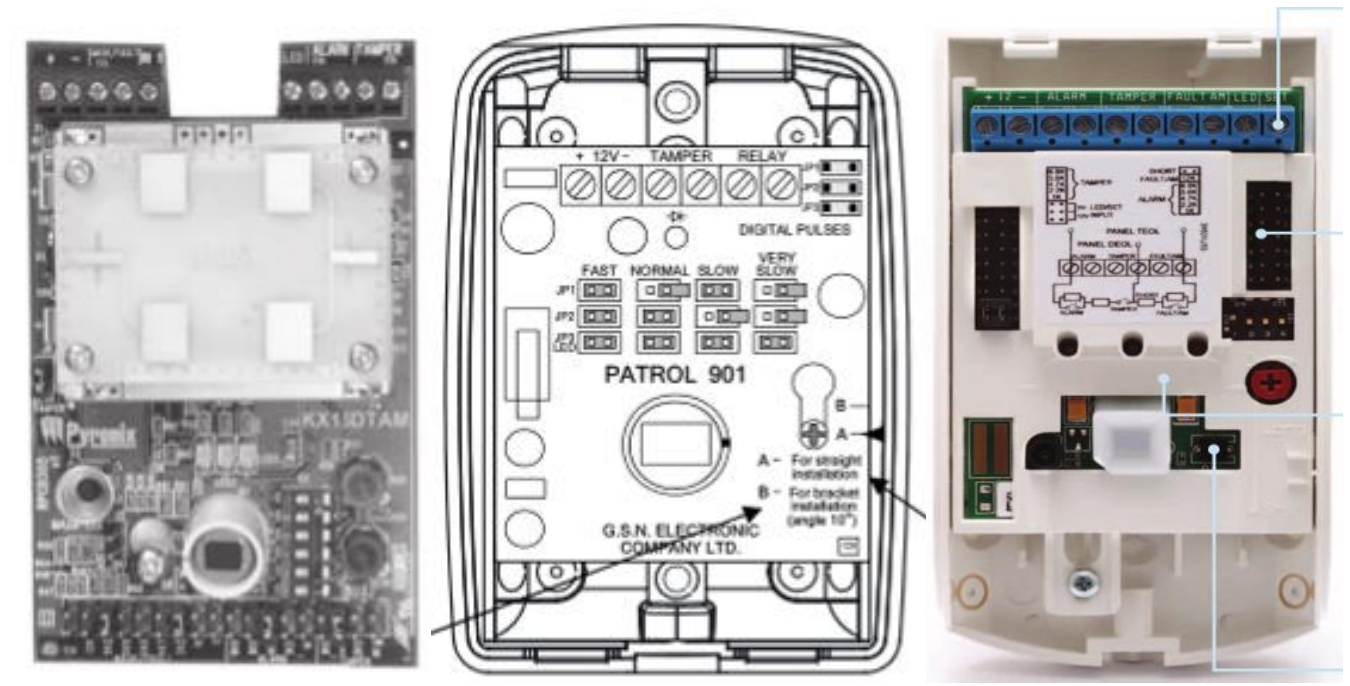

Fig.2. Controls and tuning of pyroelectric motion detectors

\section{BLOCK DIAGRAM OF A MICROELECTRO-OPTICAL INTELLIGENT PASSIVE INFRARED MOTION DETECTOR.}

A block diagram of an intelligent microelectro-optic pyroelectric motion detector is presented in Fig. 3. It consists of an optical system which is supplied with a gradient of change in the input heat flux, a controlled-sensitivity pyroelectric sensor, a selective amplifier, an ADC and a specialized microcontroller. In the role of the optical system, is a Fresnel lens with a given radiation pattern that focuses on the pyroelectric sensor thermal flows from the controlled areas.

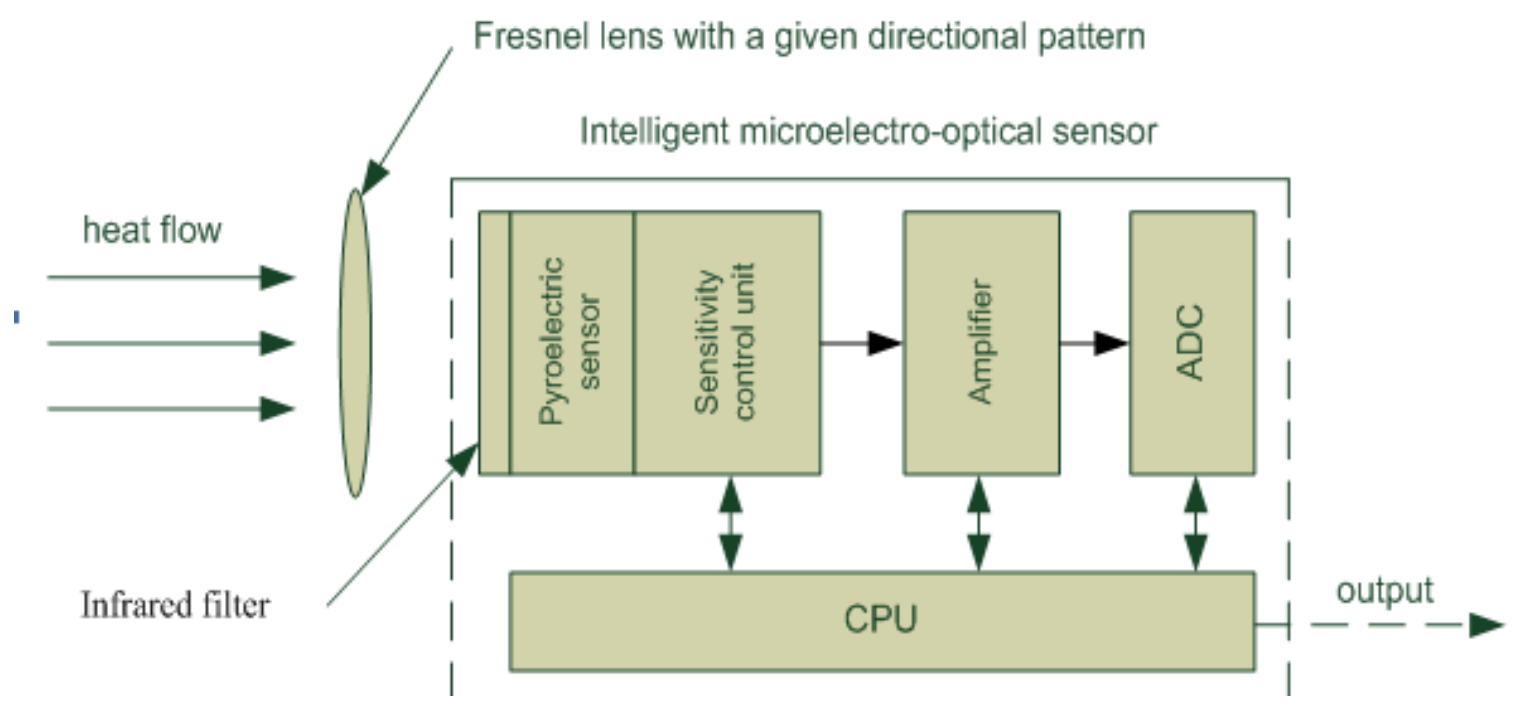

Fig. 3. Block diagram of a microelectro-optical intelligent passive infrared motion detector

\section{DETERMINATION OF BOUNDARY CONDITIONS}

Currently, there are more than a hundred companies in the world of motion detector manufacturers, each of which has more than a dozen different modifications to its product lines. That in total reaches more than 1000 different detectors using the principle of passive detection of the intruder in the detector area. Accordingly, the task of selecting the optimal detector to protect an object of a given configuration is not easy. And when it comes to improving existing motion detectors, without information about their 
parameters and specifications, the work would not be rational at all. Therefore, information and software were developed $[2,3]$ to form a database of modern passive infrared motion detectors, Fig. 4.

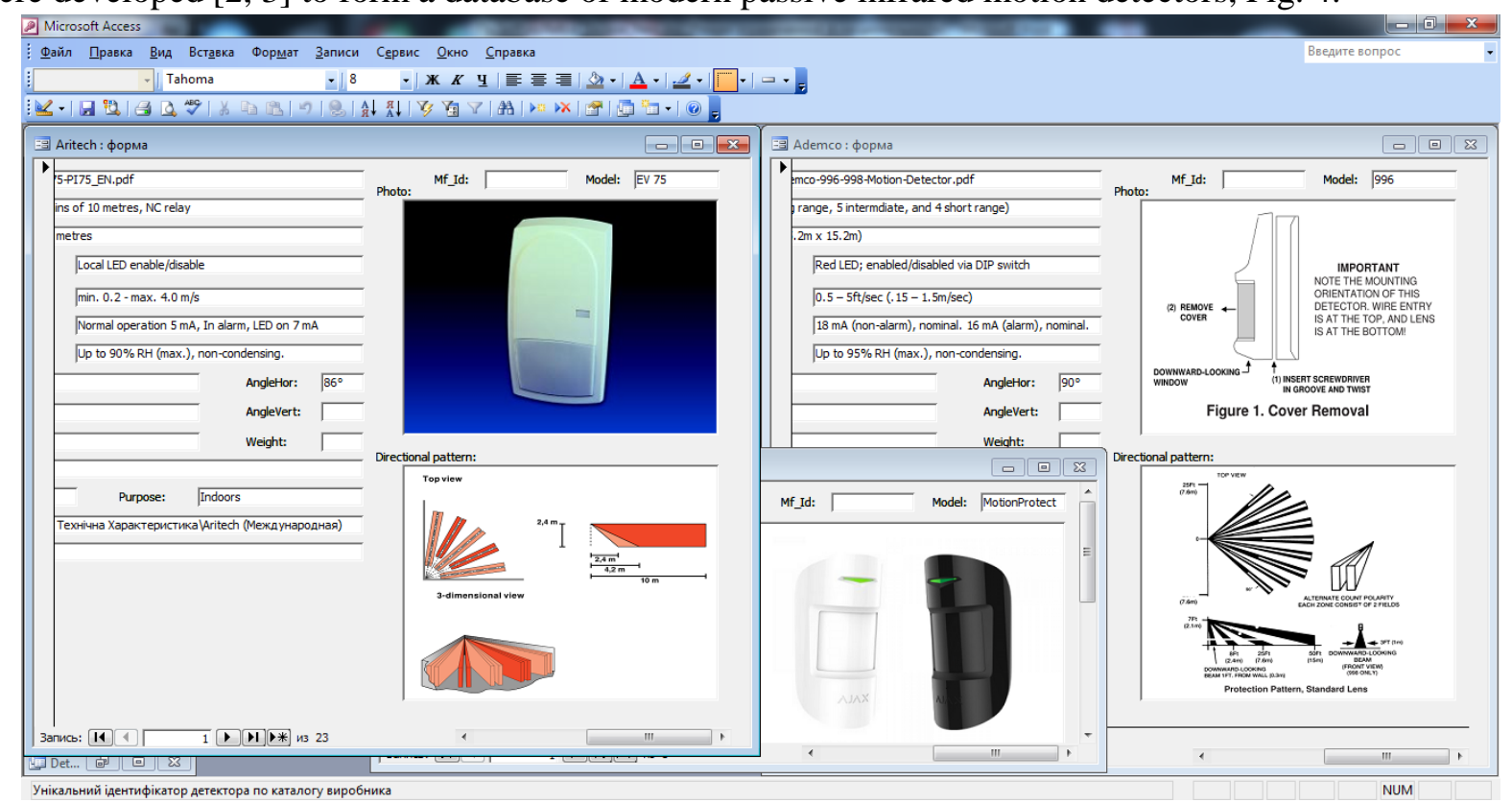

Fig. 4. Database of modern passive infrared motion detectors

The database [4] contains all the available parameters and specifications from the technical documentation available in the public domain on the website of manufacturers. At the same time, not all parameters are important, in terms of efficiency, for the development of new ones and the improvement of existing motion detectors. So according to [5] under the characteristics of passive infrared motion detectors should be considered about 28 different parameters. In this paper, attention was focused on the type of optical system, its shape, structure and dimensions of the radiation pattern of the detector.

Passive infrared motion detectors are of different purpose, different type of controlled area, range, etc. Therefore, this article examines detectors designed for indoor use, the opto-electronic principle of operation, which controls the bulk zone, which in turn is divided into three main subbands: near, middle and far. Short range detectors are considered. Models with a Fresnel-based optical system were selected among the detectors with the bulk area of the radiation pattern. On the basis of analytically synthetic processing of data from available sources for determining boundary conditions, the products of manufacturers were selected, with the minimum and maximum number of changes in the near, middle and far zones of the radiation pattern. The following results were obtained.

For the near area of the detector pattern, the minimum number of rays $K_{\text {прбмін }}=1$ is available for Ademco detectors [6] of model 4278EX. $K_{\text {прбмін }}=2$ for the Optex detectors [12] of the EX-35 model and $K_{\text {прбмін }}=4$ for the Guardall detectors [11] of the model PQ15. Therefore, the limit value is $K_{\text {прбмін }}=1$ (Fig. 5).

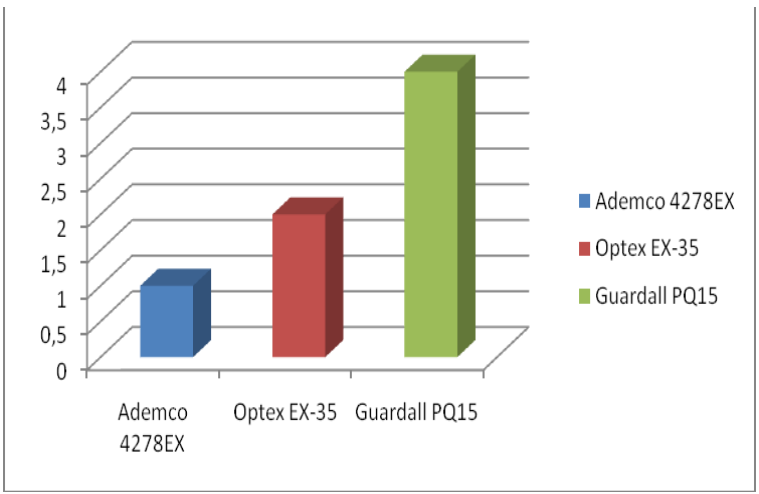

Fig. 5. The minimum number of near-beam rays of the radiation pattern of the detector 
For the near area of the radiation pattern diagram, the maximum number of rays $K_{\text {прбмакс }}=28$ is

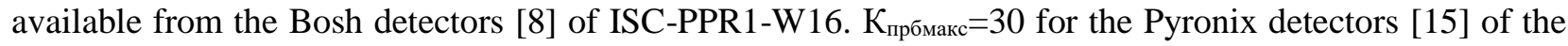
COLT QUAD PI model and $K_{\text {прбмакс }}=36$ for the DSC detectors [10] of the Strata model. Therefore, the limit value will be $K_{\text {прбмакс }}=36$ (Fig. 6).

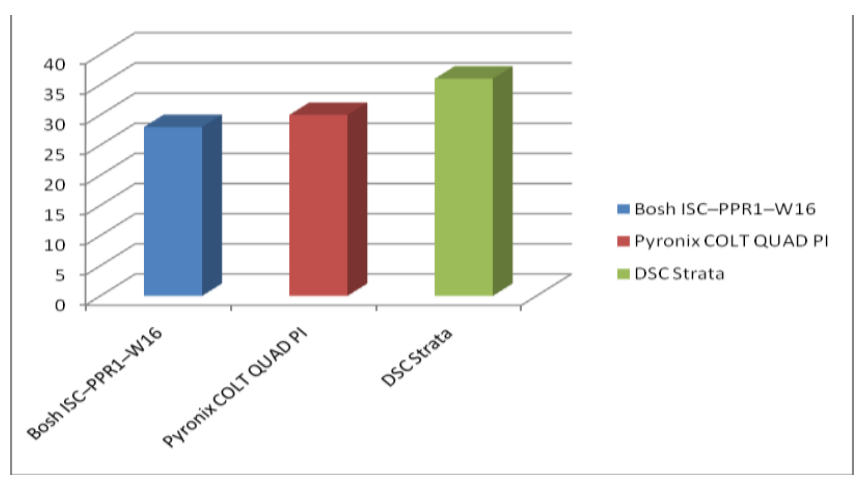

Fig. 6. Maximum number of near-beam rays of the detector pattern

For the middle zone of the detector pattern, the minimum number of rays $\mathrm{K}_{\text {прсмін }}=5$ is available for Ademco detectors [6] of Model 996. $K_{\text {прсмін }}=8$ for Crow detectors [9] MR110 and $K_{\text {прсмін }}=7$ for Velleman detectors [17] of HAA54. Therefore, the limit value is $K_{\text {прсмін }}=5$ (Fig. 7).

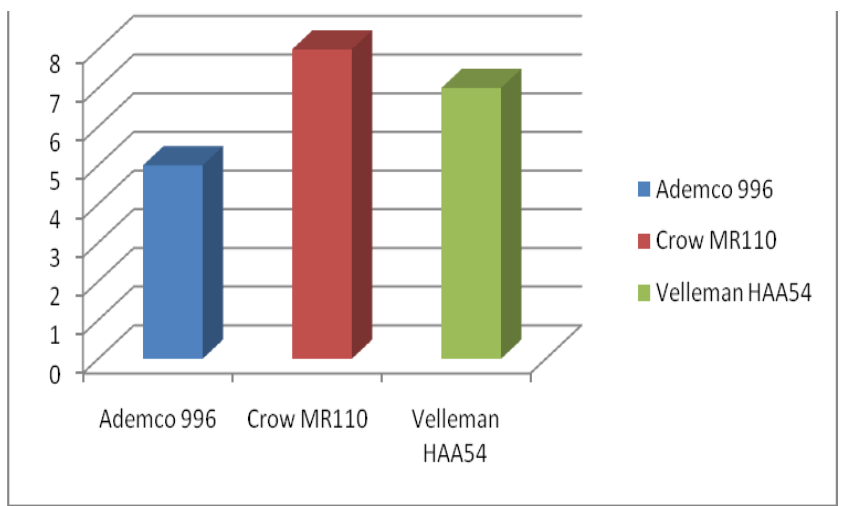

Fig. 7. The minimum number of rays of the middle zone of the radiation pattern of the detector

For the middle zone of the detector pattern, the maximum number of rays $\mathrm{K}_{\text {прсмін }}=36$ is available from the Bosh detectors [8] of the ISC - PPR1 - W16 model. $K_{\text {прсмін }}=30$ for Pyronix detectors [15] of Colt $10 \mathrm{DL}$ and $\mathrm{K}_{\text {прсмін }}=30$ for DSC [10] detectors of Bravo BV-600. Therefore, the limit value is $K_{\text {прсмін }}=36$ (Fig. 8).

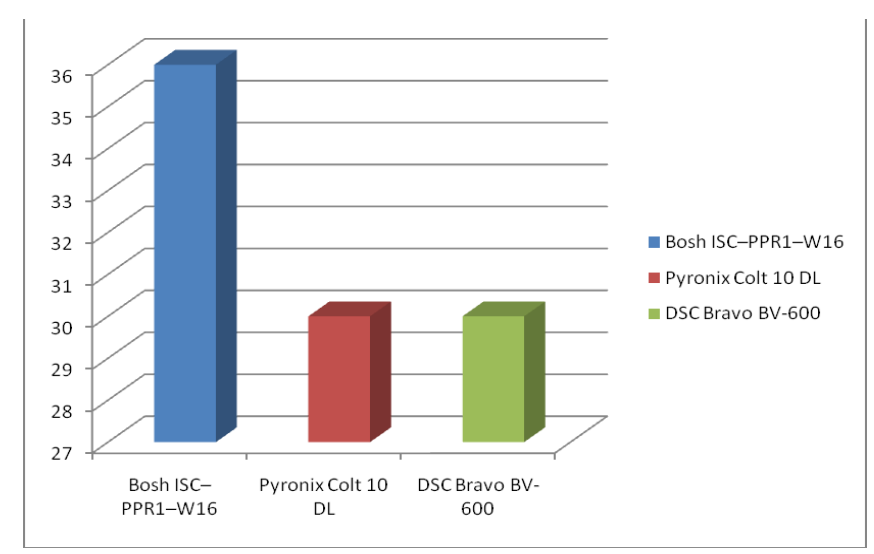

Fig. 8. The maximum number of rays of the middle zone of the radiation pattern of the detector

For the far area of the detector pattern, the minimum number of rays $K_{\text {прдмін }}=2$ is available for Aritech detectors [7] of the EV 135-P model. $K_{\text {прдмін }}=4$ for Crow detectors [9] of the GENIUS model and 
$K_{\text {прдмін }}=4$ for Ademco detectors [6] of the model 4278EX-PA. Therefore, the limit value is $K_{\text {прсмін }}=2$ (Fig. 9).

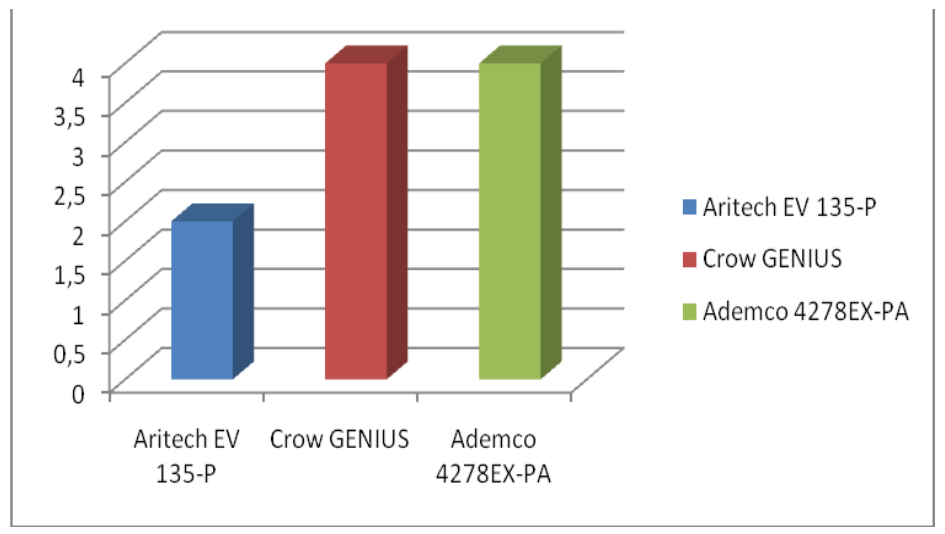

Fig. 9. The minimum number of rays of the far area of the radiation pattern of the detector

For the far area of the detector pattern, the maximum number of rays $K_{\text {прдмакс }}=26$ is available for the DSC detectors [10] of the Bravo BV-600 model. $K_{\text {прдмакс }}=27$ for Bosh detectors [8] of ISC-PPR1-WA16x model and $K_{\text {прдмакс }}=34$ for Pulnix detectors [16] of the PIR-T15WE model. Therefore, the limit value is $\mathrm{K}_{\text {прдмакс }}=34$ (Fig. 10).

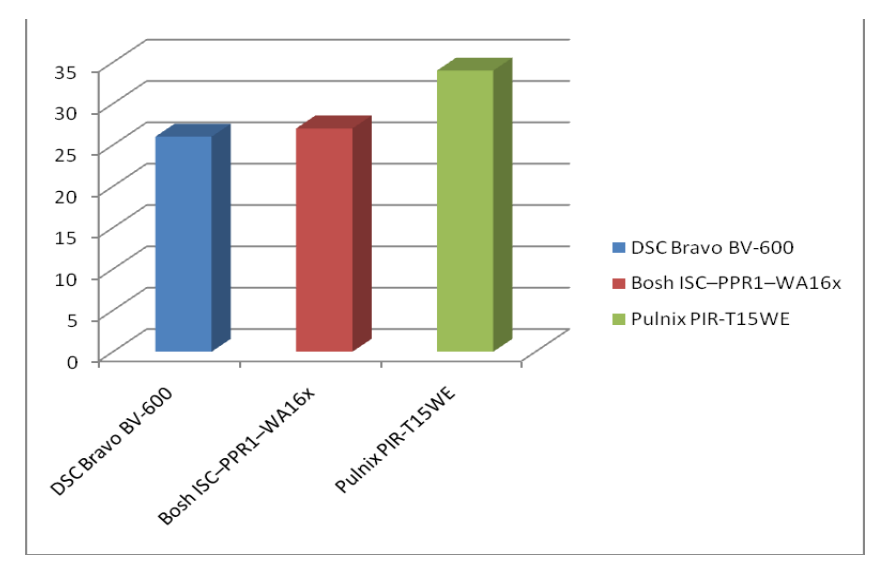

Fig. 10. The maximum number of rays of the far area of the radiation pattern of the detector

\section{CONCLUSIONS}

This article considers the principle of operation of modern passive infrared motion detectors of well-known world manufacturers, their features and areas of use. A typical structural and schematic diagram is given. From the given schematic diagram the presence of manual controls for the sensitivity of motion detectors is noteworthy! Based on the considered principle of detector operation and the conducted analytical-synthetic processing of information from primary sources [9-52], the main parameters of modern passive infrared motion detectors and their boundary conditions are determined. The analytical information collected in this article will be necessary for further modeling in computer-aided design systems in order to develop and improve existing motion detectors.

\section{REFERENCES}

[1] https://www.marketsandmarkets.com/MarketReports/ Motion-Sensor-Market-614. html Motion Sensors Market - Global Forecast to 2020, Markets and Markets.

[2] Holovatskyy R.I. Development of the software for research of objects detections of passive detectors of movement. Proceeding of the VIII-th International Conference MEMSTECH'2012 "Perspective 
Technologies and Methods in MEMS Design", 18-21 April 2012, Polyana-Svalyava (Zakarpattya), Ukraine.-Pp. 149-153.

[3] Lobur M.V., Holovatskyy R. I. Implementation of the Software for Research of Objects Detections of Passive Detectors of Movement // Scientific and Technical Jornal "Radioelectronics \& informatics", Kharkow National University of Radioelectronics, 2012, №4. ISSN 1563-0064. C. 82-85. 2012.

[4] Mykhaylo Lobur, Ruslan Holovatskyy. Development of a database for the subsystem research pyroelectric sensors // Комп'ютерні системи проектування. Теорія і практика: Вид-во Нац.ун-ту "Львів. політехніка"; № 777, 2013. - С. 7-11.

[5] BS EN 50131-2-2: 2017 "Alarm systems - Intrusion and hold-up systems - Part 2-2: Intrusion detectors - Passive infrared detectors"

[6] http://ademcosecurity.com/en-sg/solutions-sg/intrusion-detection.html - Ademco.

[7] http://aritech.pro/index.php/katalog - Aritech.

[8] https://www.boschsecurity.com/xc/en/ - Bosch.

[9] http://www.thecrowgroup.com/intrusion_detectors/ - Crow Electronic Engineering Ltd.

[10] http://www.dsc.com/dsc-security-products/c/Motion\%20Detectors/7 - DSC.

[11] https://firesecurityproducts.com/en/products/intrusion/sensors - GUARDALL.

[12] http://www.optex.net/global/group.html - Optex.

[13] https://www.paradox.com/ - PARADOX.

[14] https://www.legrand.us/home-automation-products.aspx - Pass\&Seymour Legrand.

[15] https://www.pyronix.com/ - Pyronix.

[16] https://takex.com/outdoor-pir-c-4482.php - Takex America (Pulnix).

[17] https://www.velleman.eu/products/list/?id=342361 - Velleman.

P.І. Головацький, М. В. Лобур

Національний університет “Львівська політехніка".

\section{ВИЗНАЧЕННЯ ОСНОВНИХ ПАРАМЕТРІВ ТА ЇХ ГРАНИЧНИХ УМОВ СУЧАСНИХ ПАСИВНИХ ІНФРАЧЕРВОНИХ ДЕТЕКТОРІВ PУXY}

(C) Руслан Головаџький, Михайло Лобур, 2021

Розглянуто принцип роботи сучасних пасивних інфрачервоних детекторів руху відомих світових виробників, зазначено їх особливості та сфери використання. Наведено типову структурну та принципову схеми. На основі розглянутого принципу роботи детектора та проведеного аналітико-синтетичного опрацювання інформації 3 першоджерел визначено основні параметри сучасних пасивних інфрачервоних детекторів руху та їх граничні умови. Подано граничні умови для кількості променів ближньої середньої та дальньої зон діаграми спрямованості детекторів руху. Також наведено граничні умови для напруги живлення, робочих температур та струмів споживання в різних режимах роботи.

Ключові слова - охоронні системи, ІЧ детектори руху, діаграми спрямованості, структурна схема, принципова схема, ефективність розпізнавання. 